\title{
The Spanish Society for Microbiology and Latin American microbiologists: seventy-five years of joint scientific ventures
}

\author{
Juan A. Ayala ${ }^{1}\left[\right.$ : Roberto Kolter ${ }^{2}$ \\ Received: 6 April 2021 / Revised: 6 April 2021 / Accepted: 9 June 2021 / Published online: 7 July 2021 \\ (c) The Author(s), under exclusive licence to Springer Nature Switzerland AG 2021
}

\begin{abstract}
As part of this Special Issue of International Microbiology celebrating the 75th anniversary of the founding of the Spanish Society for Microbiology (SEM), Guest Editor Rafael Giraldo invited us to contribute an opinion article on the topic of 75 years of joint scientific ventures between Latin American microbiologists and Spanish microbiologists. Since the creation of SEM in 1945 (Pérez Prieto, NoticiaSEM 98:1, 2016) Latin American microbiologists have been participants, both as individuals and as members of the national associations that are currently integrated into the Latin American Association for Microbiology (ALAM). Thus, the histories of Spanish and Latin American microbiology (Chica and Skinner, Int Microbiol 13:159-164, 2010; Chica, Int Microbiol 11:221-225, 2008) have been closely linked over the last 75 years. In order to provide our perspective on the topic, we decided to provide answers to three questions:

What are key aspects of the history of Spanish and Latin American Microbiology interactions? What have been some of our personal experiences in which these interactions shaped our careers? What is our outlook for the future of such interactions?
\end{abstract}

Keywords SEM $\cdot$ ALAM $\cdot 75$ th anniversary $\cdot$ Joint scientific venture

\section{The history of Spanish and Latin American microbiology interactions}

Juan, who for decades has been closely connected with the efforts of national societies and the Latin American Association for Microbiology (ALAM), provides his perspective.

Juan: The Latin American Microbiology Association (ALAM) is made up of National Microbiology Societies of Latin American countries, which currently actively includes the microbiology associations of Uruguay (SUM) (Soubes 2013), Argentina (AAM) (Fernández 2012), Mexico (AMM), Venezuela (SVM), Brazil (SBM), Chile (SOMICH) (Seeger and Zaldivar 2012), Paraguay (SPM), Ecuador (SEM), Peru (SOCPEMI) Colombia (ACM), and Cuba

Juan A. Ayala

jayala@cbm.csic.es

Roberto Kolter

rkolter@hms.harvard.edu

1 Department of Virology and Microbiology, Centro de Biología Molecular "Severo Ochoa, CSIC-UAM, Madrid, Spain

2 Department of Microbiology, Harvard Medical School, Boston, MA, USA
(SCMP), in order of seniority in origin and of Spain (SEM) (García Mendoza 2002) and Portugal (SPM).

The purpose of ALAM, explicitly stated in its statutes, is "to unite Microbiologists in everything that is of interest for the exercise and progress of their discipline and scientific research." Scientific associations have been, and continue to be, the elements essential through which researchers have communicated their observations and established relationships with other researchers, thus benefiting from the knowledge and opinions of their colleagues. One of the essential vehicles to carry out these ends is the congresses, where the work developed by the various participants is presented, the exchange of ideas takes place, and where many future projects are initiated.

ALAM began its journey in 1958 with the First Latin American Congress of Microbiology held in Mexico City, under the auspices of the Mexican Association of Microbiology that had been founded in 1949.

The II Latin American Congress of Microbiology took place for the first and only time in Costa Rica in 1961, when the Microbiology Societies of Uruguay, Spain, Argentina, Mexico, Venezuela, and Brazil had already been established. In these years, communication between countries 
and between different continents was poor and slow, and there are few documents on cooperation in these early years.

The III and IV Congress of ALAM took place from December 6 to 12, 1964, in Bogotá, Colombia, and in November 1967 in the city of Lima, Peru, chaired by groups of microbiologists different from the current ACM and SOCPEMI, which were founded in 2010 and 2007, respectively.

The V Latin American Congress of Microbiology was held in 1971, from December 5 to 11 in Punta del Este, Uruguay, and was held with the initially established 3-year cadence. It was sponsored by a Uruguayan Society of Microbiology that had been born in 1940, and still did not have legal personality, but that showed a strength in the American continent and where future collaborators (Felipe Schelotto, Institute of Hygiene) presented the first national publication where the determinants and genetic processes involved in the emergence and spread of antimicrobial resistance were considered.

A constant in the congresses of the 1980s and 1990s was the need to establish stronger contacts between the subsidiaries, promote the creation of microbiology societies in those countries that still had them, and disseminate the information that was carried out in each country to the rest of Latin America, since practically the only activity of ALAM had become preparing the congress, every 3 or 4 years. As of the XII ALAM Congress, which took place in Quito under the auspices of the Ecuadorian Society of Microbiology, the biennial cadence was decided and a book of minutes was maintained that has been preserved until today (Howard Junca, personal communication).

Of particular relevance for relations with Spain were the XVIII congress (held in 2006 in Pucón, Chile, and chaired by Michael Seeger) (Holmes and Mora 2006) where the entry of the SEM into ALAM as a full member was proposed, and the XIX congress (held in 2008 in Quito, Ecuador and chaired by María Fernanda Espinoza) (Seeger and Espinoza 2008) where it was ratified (Fig. 1). Ricardo Guerrero, president of SEM at that time, as a consequence of having been invited to participate as a speaker at the XVIII congress, made the initial proposal and that could only be approved in the XIX, after carrying out a modification of article three of the statutes, endorsed by Uruguay, Argentina, Paraguay, and Mexico, which allowed entry into ALAM of the societies from Spain and Portugal. Article 3 was worded as "All national microbiology associations of Latin American countries plus Spain and Portugal may be members of ALAM," which also opened the door to Portugal, which was finally admitted to the XX congress held in 2010 in Montevideo, chaired by María Hortal and organized by SUM (Seeger and Soubes 2010).

Another constant concern, evidenced in the different executive committees of each congress, and particularly at the XXII meeting held in Colombia in 2014 (Junca 2014), was the search for the signing of bilateral or multilateral agreements that would allow agreements and mutual advantages for the affiliates in each society in order to offer joint symposia, special events, dissemination, scholarships, grants, and prizes in the congresses of each national or international institution. In this sense, the XXIII congress held in 2016 in Rosario, Argentina, under the presidency of Marcelo Galas and organized by the AAM, where the FEMS (https://fems-microbiology.org) attended as a guest in the person of its president, Bauke Odega. There, the bases were laid for the elaboration of a specific ALAM-FEMS agreement with the intermediation of SEM. This agreement was already suggested in the meeting of presidents of Latin American microbiology societies that took place at the FEMS-SEM2017 congress (Aznar 2017) where there was a large participation from Latin America (161 people, 57 students and 104 seniors, 11 also members of SEM), from 14 countries, mainly from Brazil (44), Chile (41), Mexico (37), Colombia (17), and Argentina (7), and also Costa Rica (1), Panama (1), Ecuador (3), Peru (2), and Uruguay (3). Although the presidency of the XXIV ALAM congress was commissioned to prepare a text to be presented at the FEMS Executive Board that took place in Lisbon in 2017, it has not yet materialized, and it would be desirable for SEM to have an important contribution so that it could be a reality in the next XXV ALAM congress in Asunción, Paraguay, under the presidency of the Paraguayan Society of Microbiology.

From November 13 to 16, 2018, the XXIV Latin American Congress of Microbiology ALAM 2018 was held, organized by the Society of Microbiology of Chile (SOMICH) in the city of Santiago de Chile (Valiente-Echeverria 2018). It is the last one carried out so far, since the SARS-CoV-2 pandemic did not allow the XXV to be held on the scheduled date and it was delayed to August 2021. In the XXIV congress, several milestones were achieved for the first time, all of them framed by the ALAM2018 organization under the idea of fulfilling some of the sustainable development goals. The first was the celebration of fully self-financed symposia, and the second was that the summary book of the congress was developed only in digital format on the congress website, thus avoiding the unnecessary expense of almost one million two hundred thousand sheets of paper. The same idea of sustainability was behind the telephone application developed especially for this congress, which replaced the traditional schedule booklet. Likewise, the congress bags were specially designed and processed by the Inclusive Laboratory Social Development Foundation, a non-profit NGO - an initiative that is worth following and highlighting.

An invaluable means of communication for the dissemination of science are scientific journals and in particular those managed by Scientific Societies, which, although they cannot completely get rid of the commercial component that 
Fig. 1 Picture from the XIX ALAM 2008 meeting where the Spanish Society of Microbiology joined ALAM. The poster of the meeting and some people of the organizing committee are displayed, Michael Seeger, that proposed the incorporation of SEM to ALAM, and Maria Fernanda Espinoza, president of the meeting

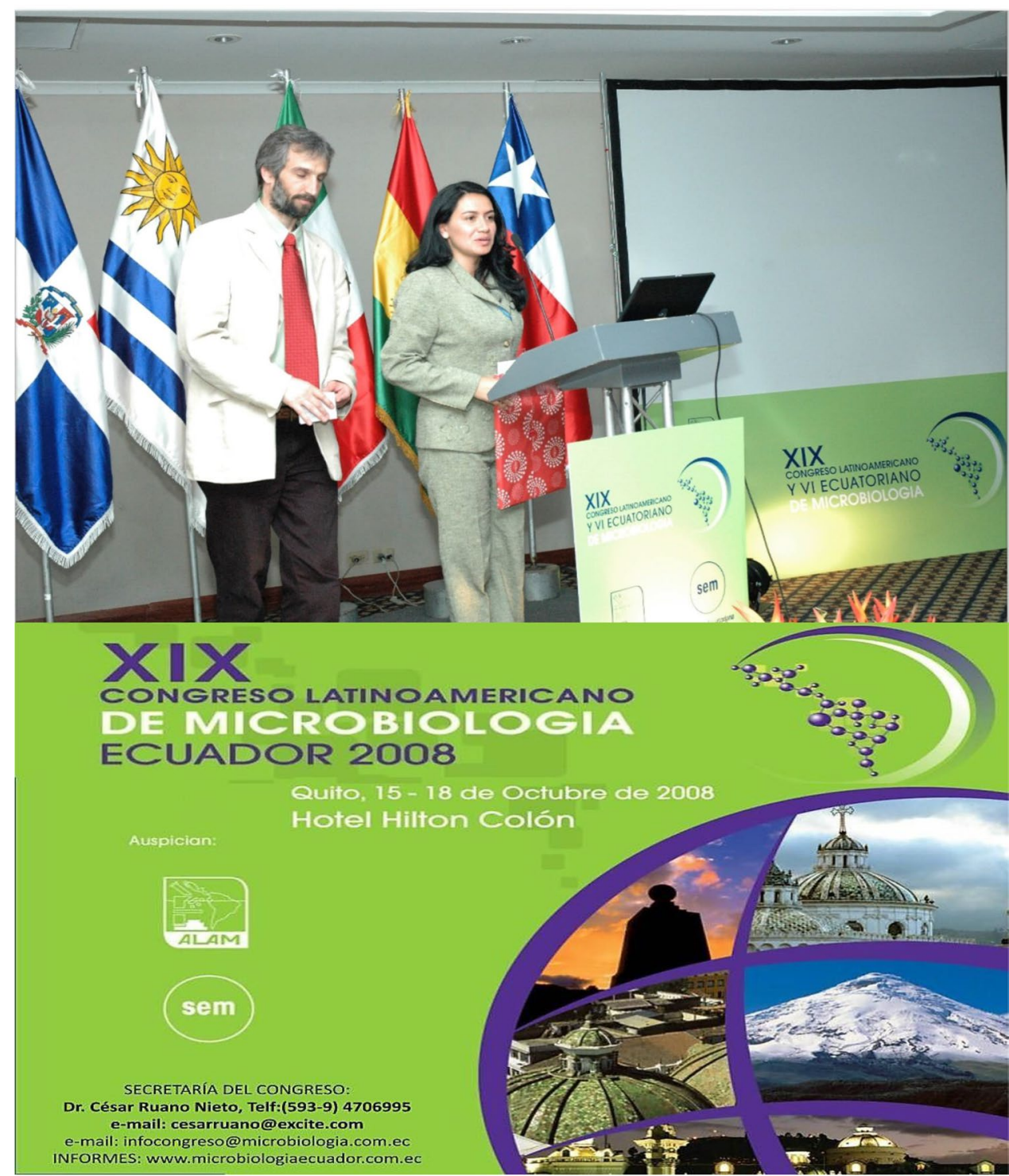

emerges today in the management of journals, have a greater possibility to evaluate the contents in a more transparent way. ALAM also managed the Latin American Journal of Microbiology (RLM) through its affiliate AMM (Mexico), with its ups and downs reflected in the meetings of the Association's executive committees. The journal was published from 1970 to 2009, with intervals of little production between 1983 and 1993. According to BIBLAT (Latin American Library of scientific and social research journals), the journal reached its best publication of 531 documents by 170 institutions and 1413 authors during 17 years. Although there were suggestions, attempts, and proposals in the different congresses for the unification of all the national journals in the RLM, and Ricardo Guerrero even proposed their integration in IM, they were never carried out. There were other different initiatives such as the creation of Latindex (Cetto 1998) of great interest to channel institutional and group resources, with which scientific publications have experienced a resurgence in quality.

One of the pillars of scientific cooperation is the possibility of achieving stable and durable communication channels between the different institutions, societies, and managers involved in the development of scientific knowledge, a fact that is not always easy, even now in the digital age. The ALAM made attempts to obtain these channels and that they were not limited to the meetings that took place between its members on the occasion of its congresses, which were initially held with a variable periodicity of between 3 and 4 years, and that from 1994 became biennial. In the minutes of the meetings of the executive committees of each new congress (I have had access to these minutes thanks to the generous collaboration of Howard Junca, current president of ACM), this urgent need was revealed, which on some occasion was reached as a critical requirement for the 
survival of the Society, and similar solutions were always proposed. In the first years, they proposed greater involvement of the subsidiaries in the organization of congresses, which was practically the only activity carried out by ALAM and which was assigned to a specific country. Given the reiteration of the proposal (García del Portillo 2012), it seems that the request was not very successful. When the digital era began and electronic communication was more fluid than letter-writing, attempts were made to institutionalize telematic channels through web page design, regular email exchange, announcements of the activities of a society on the WEB from others, newsletters, etc. At the XV ALAM in 2000 , it was proposed that Cuba, which would be the organizing country of the next congress, installs a specific ALAM web page in 2002 to provide information on the congresses and affiliates. This request is repeated at the XVIII ALAM 2006 in Pucón (Holmes and Mora 2006), under the auspices of SOMICH, and although from this congress there is evidence of the development of specific pages for each biennial meeting, the challenge was not achieved (http://alam.scien ce) until the XXIV ALAM 2019 also organized by SOM$\mathrm{ICH}$, and which has maintained continuity in the next XXV ALAM to be held in Asunción, Paraguay, for which the Paraguayan Society of Microbiology is responsible.

The SARS-CoV-2 pandemic of 2020 has left behind many events and habits, including the XXV ALAM, which has changed its date to August 2021, and has forced us to modulate what the channels of communication are and will be; the way of communication, the personal relationship, and physical contact to which we as "Latinos" are so assiduous will no longer be so critical, but the small screen, with those endless grids of participants, each one from their particular environment (we are virtually entering with the wallpapers in their homes and workplaces), will be the protagonist of the future. An advantage of this new means of communication is that it makes events much cheaper, since congressmen or participants do not need to cover travel and accommodation expenses (which are an important part of the cost of face-to-face events), and it allows meeting in just a single virtual room for scientists from anywhere in the world and those of great prestige. These digital events can be more flexible in terms of schedules and broadcast times. The Paraguayan Society of Microbiology is managing this new format very adequately, and is organizing pre-congress "Webinars" that are now in their fifth edition.

As a Latin American microbiologist that trained and practiced in theUSA his entire career, Roberto now provides a different perspective on the history of joint scientific ventures.

Roberto: My early days in training, in the 1970s, were very much focused on molecular biology. At the time microbiology and molecular biology were inseparable. For a young Latin American training in the USA, it was inspiring to learn of notable Spanish-speaking scientists. In that context learning that Severo Ochoa, working on a bacterial enzyme, had been awarded the Nobel Prize was extremely exciting. Equally inspiring was learning, a few years later, of the wonderful work done by Margarita Salas on basic aspects for bacteriophage biology. Yet, as inspiring as those individuals were, there was certainly a dearth of joint research ventures between them and Latin American scientists. I recall it that way and my recent searches for joint publications in molecular biology of that era come up largely empty.

What a world of difference 50 years have made! Fifty years after starting my training in the USA, it is evident that there are numerous joint scientific ventures between microbiologists from Spain and Latin America. The wide availability of fellowships for early career microbiologists from Latin America to carry out part of their training in Spain has resulted in many young Latin American microbiologists having strong links with Spanish microbiologists. Relationships that start as attractive training opportunities catalyzed by a common language and a shared cultural heritage become strong and long-lasting joint scientific ventures that produce outstanding science across continents.

Nowadays, there are a large and steadily growing number of collaborative projects at the frontiers of research in the microbial sciences. Take people like Victor de Lorenzo (Molecular Environmental Microbiology), Carlos PedrosAlio (Ecology of Marine Microbes), Andres Moya (Evolutionary Genetics), and Carlos Martín (Tuberculosis). These are but a few of the outstanding microbiologists from Spain who are carrying out extremely important collaborations with Latin American microbiologists and their collaborations have produced many important publications in the recent past.

\section{Personal reflections}

We now provide brief descriptions where we present how each one of us experienced the interactions between Latin American and Spanish microbiologists.

Juan: My experience with Latin America has been long and grateful, and in the three fields of Science, training of researchers, joint publications, and courses and conferences, and with the following countries, Cuba, Venezuela, Colombia, Brazil, Chile, Argentina, and Uruguay. These relationships have contributed very favorably both to my scientific career and to the development of various research projects. The greatest and deepest relationship has taken place with Argentina and Uruguay, initially through an EU project (Gutkind, G., F. Schelotto, F. Benassi, M. Martínez Tagle, M. Vives, J. Coyette, G. Amicosante, and J. Ayala. 1998. Harmonizing of the teaching and research 
between Iberoamerica and Europe on the areas of bacterial cell wall, cell division and antibiotics. European Project ALR/B7-3011/94. 04-5. 0111. 9, Network: RICERBIOMO, 1997-1999.), for cooperation in the field of academic training, of which I was coordinator and in which UdelaR (University de la República, Uruguay) a Network of American (5) and European (3) Universities, were supported by the European Union within the framework of the Alfa Program (Latin America Academic Training). Cooperation with Uruguay in the field of Microbiology and Molecular Biology regarding the mechanisms of action of antibiotics and bacterial resistance began in 1996 as a result of the preparation and approval of two ALFA projects, one for studies and the other for exchanges. In relation to this program, stays of professors Gustavo Varela (1998, Autonomous University of Madrid), Grisel Rodríguez (1998-2000, Univ. De Lieja, Belgium) and Marinela Pereira (1998-99, Univ.de L’Aquila, Italy) took place.

I have had extensive cooperation activity with the Uruguayan group, I have done 8 work internships at the Institute of Hygiene, I have received CSIC-UdelaR (Gustavo Varela, Rafael Vignoli, Inés Mota, Nicolás Cordeiro, Inés Bado) scholarship holders from 1998 to 2009 and we have developed joint research projects. I even participated as a guest in activities of the Assembly of the Faculty of Medicine, UdelaR, regarding its curricular transformation. In 2009 I was appointed Ad Honorem Professor at the UdelaR School of Medicine.

The way I understand the scientific collaborations are well reflected on the kind words professor Schelotto said at the council of the Faculty of Medicine: "to be someone who knows, and knows not only because he is informed, that information is now widely available, but because he knows how to use that information to create, to train more people, to solve problems, to progress."

The academic connections created from the Ricerbiomo project were consolidated in close cooperation ties, especially with the Argentine group of the Faculty of Pharmacy and Biochemistry: Gabriel Gutkind, Pablo Power, Marta Mollerach, José Di Conza, Marcela Radice.

These links have been developed over the years 1996 to 2010 through courses, internships, and researched work on the following topics: Mechanisms of action of Antibiotics, Mechanisms of Bacterial Resistance; Search for New Targets and Development of new Antibacterials.

Of particular relevance was the internship in 2010, which served to refine work methods and projects on shared topics, to give continuity to collaborative work and to plan new academic exchanges. My activity was focused on supporting the research team during the internship period, during which time I also collaborated with an exhibition on "Type III secretion systems" in the postgraduate course organized by the Department on "Escherichia coli, a versatile pathogen: Results of the working groups related to enteric and urinary pathogens and antimicrobial resistance."

My relationship with Cuban science began in 1996, when a student from the Center for Industrial Biotechnology Studies (CEBI) at the Universidad de Oriente in Santiago de Cuba contacted me to begin the characterization of multiresistant Pseudomonas strains isolated in Cuba. Dr. Rosa Catalina Bermúdez was the Director of CEBI in 1992, when her first working relationships began with Dr. Angeles Manresa, who was head of the Microbial Surfactants Laboratory of the Faculty of Pharmacy of the UB. In 1994, Dr. Manresa visited the Universidad de Oriente, and I did myself in 1996, and cooperative relations began to be strengthened for the formation of human capital at CEBI, considering that $80 \%$ of the workforce were young Graduates of the careers of Chemistry, Biology, Biochemistry, Pharmaceutical Sciences, Economics and Chemical Engineering that were part of the Scientific Reserve of the Center. On the other hand, there was only one Doctor of Science (Chemistry). Since 1998, collaborative actions have materialized through projects and scholarships financed by AECID (Spanish Agency for International Development Cooperation), as well as the improvement of CEBI professor-researchers through postgraduate courses taught by Spanish specialists (Angeles Manresa, Ana María Solanas, Juan Ayala, Tomás González Villa, Mercedes Ballesteros Perdices, José Manuel Gómez and Domingo Cantero) and joint participation in international events. All those who appear as recipients (Rosa Pérez, Manuel Serrat, Guillermo Cobas, Irasema Pérez, Emiliano Díaz, Víctor Deroncelé, Maikel Fernández, Juan Almenares and Amarilis Rodríguez) enjoyed AECID or Andalusian government scholarships in Spanish universities and they developed part or all of their research in microbiology laboratories where they studied collectible or autochthonous microorganisms isolated from different contaminated environments in Cuba. These autochthonous microorganisms (Pseudomonas aeruginosa, environmental (producing rhamnolipids, lipoxygenases, and degrading hydrocarbons) and from hospital environments (antimicrobial resistance study); Desulfovibrio sp. for the removal of heavy metals and degradation of HCs. Kluyveromyces marxianus, isolated from coffee residues produces pectins) were identified, preserved, manipulated in laboratories and universities in close connection with the Spanish Society of Microbiology (SEM) and the Spanish Collection of Type Cultures (CECT) and there are several publications in this regard. And the link with our society was established through the University of Barcelona (Arelis Abalos), University of Santiago de Compostela (Manuel Serrat), University of Cádiz (Rosa Pérez), University of Murcia (Amarilis Rodriguez), Severo Ochoa Molecular Biology Center (Guillermo Cobas, Emiliano Díaz), and Complutense University of Madrid (Juan 
Almenares). All the actions discussed here began in 1998 and ended in 2011.

Roberto: From the very outset, my career as a head of laboratory was greatly influenced by interactions with Spanish microbiologists. As a Latin American graduate student training in the USA, I was constantly searching for publications from Spanish-speaking microbiologists. That is how I came across the 1976 paper by Carlos Asensio and colleagues describing his discovery of the microcins (Asensio et al. 1976). As soon as I started my own laboratory in 1983, I reached out to Spain to initiate a collaboration. Sadly, Carlos had died tragically in 1982 but I was fortunate to connect with Felipe Moreno. We worked together for several years on microcins generating a wonderful two-way street between Boston and Madrid (Kolter and Moreno 1992). Among the many Spaniards to come to my lab was Olga Genilloud, who now heads the Medina Foundation in Granada. Importantly, during my visits to Madrid, I connected with several Latin Americans who returned to establish laboratories in their home countries. As a result, there is still much fascinating work on microcins (now known as members the RiPP family of peptide antibiotics) going on in Latin America.

Importantly, during my multiple visits to Spain, I had the opportunity to meet many outstanding Spanish microbiologists and establish long-lasting friendships with them. One of the people I met during an early visit to Spain proved instrumental to my career: Antonio Tormo, then professor at Universidad Complutense de Madrid. He spent two short sabbaticals in my laboratory and helped initiate the field of studying non-growing or extremely slow-growing bacteria. The work that he did in my lab was done together with two outstanding Latin American students who returned to their home countries to lead laboratories of their own: Marta Almirón in Argentina and Maria Mercedes Zambrano in Colombia (Zambrano et al. 1993).

Throughout the following decades, I was fortunate to have several Spanish microbiologists train as post-doctoral fellows in my laboratory and then return to Spain to develop their scientific careers: Manolo Espinosa-Urgel (Granada), Esteban Martínez (Madrid), Daniel Lopez (Madrid), Diego Romero (Málaga).

In 1992, I was invited to participate in the ISME6 in Barcelona, where I met Ricardo Guerrero for the first time. It was the beginning of a wonderful friendship. Ricardo routinely connected me with undergraduate students from Barcelona who would carry out summer training in my lab. Also, when I was ASM President in 2009, Ricardo invited me to speak at the SEM annual meeting in Almería (Martin 2009). What a delight it was to participate in the SEM event and, to add icing on the cake, to have the honor of meeting the distinguished Colombian scientist Nubia Muñoz, whose work on papillomavirus and human cervical cancer is among the most important scientific contributions. She most certainly exemplifies the very best of joint scientific ventures involving Latin America and Spain.

I would like to add that as my career progressed, I participated in several of the ALAM meetings. Of these, I have many recollections of Spanish microbiologists making outstanding presentations. Most memorable of these is perhaps the opportunity I had in Santiago, Chile, to hear and then personally meet, Francisco Mojica of CRISPR fame. Someone I had already admired and met through the ether. The ALAM meeting gave me that wonderful opportunity.

\section{Views toward the future}

\section{Overview}

We are confident that the scientific relationships between microbiologists from Latin America and Spain will continue to grow in the future. What would we like to see happen in the future? Up to now, incentives to interact have been largely through participation in international meetings such as the ALAM and SEM congresses and through the offering of training fellowships for students from Latin America to obtain their $\mathrm{PhD}$ degrees in Spanish laboratories. Our sense is that one key problem facing Latin America (and perhaps also Spain) is that there already may be a surplus of individuals with $\mathrm{PhDs}$ because there are not enough jobs for them once their training is finished. We believe that we should strive to develop programs that allow independent investigators to visit laboratories in the other continent, i.e., Spanish microbiologists to spend 3-12 months in Latin American laboratories and vice versa. Such programs will greatly stimulate new collaborations that will benefit everyone's scientific development.

On the occasion of the 50th anniversary of the founding of the SEM, the journal Microbiologia SEM published a series of editorials by various researchers (Schaechter and Orrego 1996; Ayala 1996; Halvorson 1996) of known scientific quality and at the same time direct knowledge of the subject, on the situation of Microbiology in Latin America, where many of the aspects listed below were already reflected and the most appropriate aids that we would be able to offer from Europe were indicated.

\section{Funding issues}

Funding issues have been and will continue to be a key limiting factor. The economy of both Spain and Latin American countries has been heavily affected by COVID. One of the main challenges correlates to new economic changes caused by COVID. This might mean less available resources to support science and less opportunity for collaboration. 


\section{Joint ventures with Spanish groups}

The main opportunity and at the same time a challenge for the future would be in the establishment of cooperation programs between Spanish researchers and researchers from Latin American countries for the formulation and execution of joint research projects, which are based on the strengths of each group. Another opportunity would be in the development of joint doctorates that have a virtual component.

Research in Latin America has remained difficult throughout the years. This has been largely due to recessive economies that put research the continuity of projects in danger and impair the possibility of acquiring modern and updated equipment and technologies. In this sense, it is really important to keep collaborative programs with foreign colleagues, and SEM is still one of the stronger partners in some of our ongoing research projects.

Latin American countries must invest more in science and technology, for a development that depends basically on knowledge. Traditionally, it has depended on the repetition of imported knowledge and technology, and national or regional research has been mistrusted. The SEM could perhaps cooperate in promoting joint programs that allow for the addition of international cooperation funds that are not easily accessible.

Academic training in Spanish centers of excellence and exchanges of researchers in both directions are also very beneficial actions that require promotion, organization, and dedication. The basic training, intellectual capacity, and conduct of Latin American technicians are recognized as favorable at the international level, and constitute an important foundation that allows confidence in the good results of training efforts.

The vertiginous development of Microbiological Sciences of the last two decades augurs a promising future to face the main environmental and inequality problems facing the region. These include overexploitation of natural resources, unhealthy conditions, multiresistance to antibiotics, prevention and treatment of infectious diseases in animals and plants, environmental contamination, and food insecurity, among others. In all these spheres, Microbiological Sciences and related technologies such as microbiomics, genomics, proteomics, nanotechnology, biotechnology, bioinformatics, etc. can support sustainable agricultural and animal production and the obtaining of new materials, products, and processes. Because the endemicity of animals and plants in the region is very high and there is a close relationship between it and microbial biodiversity, there is a high probability of finding new products derived from such genetic resources to be used in the agricultural and pharmaceutical industries, cosmetics, and biotechnology. Despite these potentialities, the countries of the region have a limited scientific infrastructure and only attract about $3 \%$ of all research and development projects of global foreign direct investment. In this sense, the SEM together with the ALAM and other cooperation agencies could play a leading role to attract capital and promote competitive Collaboration Projects in Microbiological Sciences that promote the joint development of the Latin American countries.

One collaborator for Uruguay (now a member of the board of directors of SUM) told me that it would be very good if SUM could sign with SEM an agreement of the type that we already have signed with the AAM, the SBM, and the SOMICH, within the framework of which the partners of one society enjoy the rights of the partners of the other, regarding participation in courses and conferences. It would also be good if the SEM (as does the ASM) could organize a network of SEM ambassadors in each Latin American country, who would act as a link between the local microbiological community and the SEM, disseminating and proposing activities. This works very well for the ASM, as they have many new followers/partners from Latin America (it has also sponsored numerous activities related to microbiology).

\section{New technologies accessibility}

As has often happened in other serious historical situations, dramatic moments of crisis often turn into opportunities for technological development. During the current pandemic, microbiology has been already embarked on an authentic diagnostic revolution. Systems based on proteomics or genomics had already broken through, which have made it possible to reduce laboratory response times to limits unthinkable just a few years ago.

We can now know the genome of a microorganism in a matter of hours, or study the microbiome of a person in a very reasonable time. We have automated robotic equipment that allows us to sow a clinical sample, or perform a diagnostic process without any manual manipulation; digital technology has been incorporated into microbiological diagnosis; we have biosensors that can perform an analytical process with minimal amounts of sample in record time; etc. All this technology should be made accessible to Latin American laboratories by cooperation with Spanish counterparts.

Acknowledgements We would like to acknowledge all the people who have contributed to this article with their comments and suggestions, which have been already mentioned in the text, and also Ricardo Medina, Marcelo Galas, Lucia Yim, and very especially Felipe Schelotto for his friendship and Michael Seeger and Maria Fernanda Espinoza for the pictures. We also thank Ricardo Guerrero for his thoughts on the topic.

Authors' contribution The individual contributions of JAA and RK were to conceive and to write the manuscript. 


\section{Declarations}

Conflict of interest The authors declare no competing interests.

Consent for publication Michael Seeger, who proposed the incorporation of SEM to ALAM, and Maria Fernanda Espinoza, president of the meeting, appearing on Fig. 1, gave their consent for the publication.

\section{References}

Asensio C, Perez Diaz JC, Martínez MC, Baquero F (1976) A new family of low molecular weight antibiotics from Enterobacteria. Biochem Biophys Res Commun 69:7-14. https://doi.org/10.1016/ S0006-291X(76)80264-1

Ayala FJ (1996) La ciencia en América Latina. Microbiología SEM 12(2):163-166 https://www.semicrobiologia.org/storage/secci ones/sociedad/historico_revista/12_2.pdf

Aznar R. (2017) Congreso FEMS-SEM 2017. SEM@ foro 64:13-14. https://www.semicrobiologia.org/storage/secciones/publicaciones/ semaforo/64/articulos/4-CongresoFEMS-SEM.pdf

Cetto AM (1998) Ciencia y producción científica en América Latina. El proyecto Latíndex. International Microbiology 1:181-182 http:// revistes.iec.cat/index.php/IM/article/viewFile/37/36

Chica C. (2008) Microbiology in Latin America and the ALAM. International Microbiology 11:221-225. https://doi.org/10.2436/ 20.1501.01.64. http://revistes.iec.cat/index.php/IM/article/viewF ile/9674/9669

Chica C, Skinner N (2010) Looking for a place in the sun: science and technology in Latin America. Int Microbiol 13:159-164. https:// doi.org/10.2436/20.1501.01.121

Fernández MIG (2012) Historia de la Asociación Argentina de Microbiología SEM@foro 54:14-16 https://www.semicrobiologia.org/ storage/secciones/publicaciones/semaforo/54/articulos/06\%20Soc iedades\%20Hermanas.pdf

García del Portillo F. (2012) Crónica del XXI Congreso de la Asociación Latinoamericana de Microbiología (ALAM). NoticiaSEM 58:3-4 https://www.semicrobiologia.org/storage/secciones/publi caciones/noticias/58.pdf

García Mendoza C (2002) Historia de la Sociedad Española de Microbiología a lo largo del siglo XX. en Historia de la Sociedad Española de Microbiología a lo largo del siglo XX. Editorial Centro de Estudios Ramón Areces, Madrid. pp. 17-118

Halvorson HO (1996) Instituciones de apoyo a la microbiología en Cuba. Microbiología SEM 12(3):343-346 https://www.semic robiologia.org/storage/secciones/sociedad/historico_revista/12_3. pdf

Holmes DS, Mora G (2006) Taking the pulse of Latin American microbiology: the 18th ALAM congress (Pucón, 23-26 October 2006).
Int Microbiol 9:306-308. http://revistes.iec.cat/index.php/IM/artic le/viewFile/9591/9587

Junca H (2014) Colombia, punto de encuentro de la Microbiología mundial en 2014: Un sueño que se cumple, progreso humano que se comparte y hermandades que se fortalecen. Hechos Microbiológicos 5(2 Sup 2): 1

Kolter R, Moreno F (1992) Genetics of ribosomally synthesized peptide antibiotics. Ann Rev Microbiol 46:141-163. https://doi.org/ 10.1146/annurev.mi.46.100192.001041

Martin H (2009) XXII Congreso SEM: "De biopelícula en Almeria. SEM@ foro 48:32-35. https://www.semicrobiologia.org/storage/ secciones/publicaciones/semaforo/48/articulos/9.\%20Martin20 09.pdf

Pérez Prieto SI (2016) 70 Aniversario de la fundación de la SEM. NoticiaSEM 98:1. https://www.semicrobiologia.org/storage/secci ones/publicaciones/noticias/98.pdf

Schaechter M, Orrego C (1996) Una perspectiva sobre la investigación microbiológica latinoamericana. Microbiología SEM 12(1):7-8. https://www.semicrobiologia.org/storage/secciones/sociedad/histo rico_revista/12_1.pdf

Seeger M, Espinoza MF (2008) Highlights of Latin American microbiology: the 19th ALAM Congress. Int Microbiol 11:289-292. https://doi.org/10.2436/20.1501.01.74

Seeger M, Soubes M (2010) Latin American microbiology at the independence bicentenary: the 20th ALAM Congress (Montevideo, 27-30 September 2010). Int Microbiol 13:213-218. https://doi. org/10.2436/20.1501.01.128

Seeger M, Zaldivar M (2012) Historia y desarrollo de la Sociedad de Microbiología de Chile. SEM@foro 53:11-13. https://www.semic robiologia.org/storage/secciones/publicaciones/semaforo/53/artic ulos/p11\%2053.pdf

Soubes M (2013) Pasado, Presente y Futuro de la Sociedad Uruguaya de Microbiología. SEM@ foro 55:16-17. https://www.semicrobio logia.org/storage/secciones/publicaciones/semaforo/55/articulos/ 07_Sociedades_hermanas_55.pdf

Valiente-Echeverria F (2018) $24^{\circ}$ Congreso Latinoamericano de Microbiología en Chile (13-16 noviembre de 2018). NoticiaSEM 125:6. https://www.semicrobiologia.org/storage/secciones/publicaciones/ noticias/125.pdf

Zambrano MM, Siegele DA, Almirón M, Tormo A, Kolter R (1993) Microbial competition: Escherichia coli mutants that take over stationary phase cultures. Science 259:1757-1760. https://doi.org/ $10.1126 /$ science.7681219

Publisher's note Springer Nature remains neutral with regard to jurisdictional claims in published maps and institutional affiliations. 